\title{
Hemşirelerin Mesleki Tatmin, Tükenmişlik ve Eşduyum Yorgunluğu Düzeylerinin İncelenmesi: Bir Üniversite Hastanesi Örneği $\infty$
}

\author{
Yağmur ÇOLAK YILMAZER ${ }^{1}$, Kadriye BULDUKOĞLU
}

\section{ÖZ}

Amaç: Bu çalışma, hemşirelerin mesleki tatmin, tükenmişlik ve eşduyum yorgunluğu düzeylerini ve ilişkili faktörleri belirlemek amacıyla yapılmıştır.

Gereç ve Yöntem: Bu araştırma, Akdeniz Üniversitesi Hastanesi'nde Nisan-Mayıs 2017 tarihlerinde 118 hemşirenin verileri incelenerek yürütülen tanımlayıcı bir çalışmadır. Veriler "Kişisel Bilgi Formu" ve "Çalışanların Yaşam Kalitesi Ölçeği" (ÇYKÖ) kullanılarak toplanmış olup SPSS 20.0 paket programında analiz edilmiştir. Verilerin değerlendirilmesinde, tek yönlü ANOVA ve $t$ testi kullanılmıştır. Ayrıca ÇYKÖ alt boyutları olan mesleki tatmin, tükenmişlik ve eşduyum yorgunluğu arasındaki ilişkiyi belirlemek için Pearson korelasyon analizi yapılmıştır.

Bulgular: Araştırmada hemşirelerin mesleki tatmin, tükenmişlik ve eşduyum yorgunluğu düzeylerinin, yaş, çocuk sahibi olma, mesleğini isteyerek seçme ve vardiyalı çalışma düzeniyle ilişkili olduğu bulunmuştur. Çalışmada ayrıca mesleki tatmin ve tükenmişlik düzeyleri arasında ters yönlü ve orta düzey bir ilişki olduğu ( $r=-0.618 ; p<0.001)$, tükenmişlik ile eşduyum yorgunluğu düzeyleri arasında ise pozitif ve anlamlı bir ilişki olduğu saptanmıştır $(r=0.580 ; p<0.001)$.

Sonuç: $\mathrm{Bu}$ çalışmada, çalışanların yaşam kalitesinin temel parametreleri olan mesleki tatmin, tükenmişlik ve eşduyum yorgunluğunun kişisel ve mesleki özellikler ile ilişkili olduğu saptanmıştır.

Anahtar kelimeler: Hemşireler, merhamet yorgunluğu, tükenmişlik, yaşam kalitesi

\begin{abstract}
Assessment of Compassion Satisfaction, Burnout and Compassion Fatigue Levels of the Nurses: A University Hospital Example

Aim: This study aims to determine the levels of compassion satisfaction, burnout, and compassion fatigue of nurses and related factors.

Material and Methods: This descriptive study was conducted by examining the data of 118 nurses working at Akdeniz University Hospital between April and May 2017. The data were collected with "Personal Information Form" and "Professional Quality of Life Scale" (ProQOL) and analyzed in SPSS 20.0 package program. Oneway ANOVA and t-test were used to evaluate the data. Furthermore, Pearson correlation analysis was used to determine the relationship between compassion satisfaction, burnout, and compassion fatigue which are subdimensions of ProQOL.

Results: The study has revealed compassion satisfaction, burnout, and compassion fatigue levels of the nurses are associated with age, having children, choosing this profession voluntarily, and working in shifts. It was also found that there is a negative and moderate relationship between compassion satisfaction and burnout levels $(r=-0.618 ; p<0.001)$ and a positive and significant relationship between burnout and compassion fatigue levels $(r=0.580 ; p<0.001)$. Conclusion: In this study, it was determined that compassion satisfaction, burnout, and compassion fatigue, which are the basic parameters of the quality of life of employees are associated with personal and professional characteristics.

Keywords: Burnout, compassion fatigue, nurses, quality of life
\end{abstract}

${ }^{1}$ Öğr. Gör., Akdeniz Üniversitesi Hemşirelik Fakültesi, Psikiyatri Hemşireliği Anabilim Dalı, Antalya, Türkiye, E-posta: yagmur_yagiyo@hotmail.com, Tel: +90 242 226 13 58-2947, ORCID:0000-0002-2926-1306

2Prof. Dr., Akdeniz Üniversitesi Hemşirelik Fakültesi, Psikiyatri Hemşireliği Anabilim Dalı, Antalya, Türkiye, E-posta: bkadriye@akdeniz.edu.tr, Tel: +90 242 226 13 586123, ORCID:0000-0002-1699-6151

Geliş Tarihi: 08 Nisan 2020, Kabul Tarihi: 17 Şubat 2021

Atıf/Citation: Çolak Yılmazer Y, Buldukoğlu K. Hemşirelerin Mesleki Tatmin, Tükenmişlik ve Eşduyum Yorgunluğu Düzeylerinin İncelenmesi: Bir Üniversite Hastanesi Örneği. Hacettepe Üniversitesi Hemşirelik Fakültesi Dergisi 2021; 8(2): 144-150. DOI: 10.31125/hunhemsire.966330 


\section{GiRiş}

Hemşirelik insanların yaşamının en zorlu dönemlerinde onların yanında olan sürekli ağrı, acı ve güçsüzlüklerin yaşandığı ortamlarda bakım sunan manevi açıdan yüklü bir meslektir. Böylesine zorlu koşullarda hemşireliğe katkı sağlayan özelliklerden biri ve en önemlisi empatik bakım verebilme becerisidir ${ }^{1}$. Empati yapabilme becerisi, başkalarına yardım etmede önemli bir yere sahiptir ${ }^{2,3}$. Empati sayesinde hemşireler hastaların değer yargılarını, endişelerini anlayabilir, merhametli olabilme yönünde motive olabilir ve hastalarıyla terapötik iletişim kurmaya istekli olurlar ${ }^{4,5}$. Figley (2002), şefkatli ve empatik olabilmenin bir bedeli olduğunu vurgulamış, bu durumu 'Compassion Fatigue' olarak ifade etmiştir ${ }^{6}$. Bu araştırmada ölçekle de uyumlu olmak üzere kavramın Türkçe karşılığı olarak 'Eşduyum Yorgunluğu' kullanılmıştır ${ }^{3,7}$. Eşduyum yorgunluğu en genel tanımıyla acı çeken insanlar ile çalışan kişilerde görülen duygusal, psikolojik ve ruhsal yıpranma olarak açıklanmıştır6,8. Eşduyum yorgunluğu, tükenmişlik ile birlikte bulunabilir, ancak birbirinden farklı kavramlardır. Tükenmişlik kişinin gündelik yaşam ile başa çıkma yeteneğinin tükenmesi nedeniyle duygusal ve zihinsel anlamda ortaya çıkan yorgunluk halidir. Bireyin tükenmişlik deneyimi işi bırakmasının hemen ardından düzelebilirken, eşduyum yorgunluğu koşulları değiştirmekle ortadan kalkmaz ${ }^{6}$. Bu bağlamda tükenmişliğin temel bileşenlerinden biri olarak mesleki tatmini de göz önüne almak gerekmektedir. Mesleki tatminin azalması kişinin hayatındaki olumsuz yaşam olaylarıyla ve kişilik özellikleriyle de birleşince, genellikle, huzursuzluk, öfke, anksiyete, depresyon, yorgunluk gibi öznel duygulanımlara ve çeşitli fizyolojik sorunlara yol açmaktadır9,10.

Hemşireler sağlık insan gücünün önemli bir bölümünü oluşturan, hasta gereksinimlerini belirleyen, bakımı planlayan, uygulayan, bakımın etkinliğini değerlendiren ve aynı zamanda sağlık ekibi üyelerinin koordinasyonunu sağlayan bir meslek grubudur. Bu durum onları çalışma koşulları ve alanları bakımından riske maruz bırakmaktadır ${ }^{11}$. Sonuçta hemşireler, bu riskler önlenmediği takdirde, düşük mesleki tatmin, tükenmişlik ve eşduyum yorgunluğu ile karşılaşmaları kaçınılmaz olmaktadır.

$\mathrm{Bu}$ temel bilgiler ışığında; hemşirelerin beden ve ruh sağığının korunması, çalışma yaşamının ve işyerinin zorlu koşullarından, toplumsal kaynaklı zararlı etkenlerden en az düzeyde etkilenmesinin sağlanması son derece önemlidir. $\mathrm{Bu}$ nedenle mesleki tatminsizlik, tükenmişlik ve eşduyum yorgunluğunun risk faktörlerini ve belirtilerini tanımanın ilk adım, önleme ve iyileştirme çalışmalarının bir sonraki adım olacağı öngörülmektedir 6 .

\section{Araştırmanın Amacı}

$\mathrm{Bu}$ araştırmanın amacı, hemşirelerin mesleki tatmin, tükenmişlik ve eşduyum yorgunluğu düzeyleri ile ilişkili faktörlerin belirlenmesidir.

\section{Araştırmanın Hipotezleri}

1. $\mathrm{H}_{1}$ : Hemşirelerin tanıtıcı ve mesleki özelliklerinin, mesleki tatmin, tükenmişlik ve eşduyum yorgunluğu düzeyleriyle ilişkisi vardır.
2. $\mathrm{H}_{1}$ : Hemşirelerin mesleki tatmin, tükenmişlik ve eşduyum yorgunluğu düzeyleri arasında ilişki vardır.

\section{GEREÇ ve YÖNTEM}

\section{Araştırmanın Türü}

Bu araştırma tanımlayıcı bir çalışmadır.

\section{Araştırma Evren ve Örneklemi}

Araştırmanın evrenini Akdeniz Üniversitesi Hastanesinde çalışan 670 hemşire oluşturmuştur. Başlangıçta, elde edilen verilerin analizinde kullanılacak testlerde en az \%80 güç sağlayabilmek amacı ile ulaşılması gereken minimum hemşire sayısı belirlenmiştir. Bu amaçla GPower3.1 programı kullanılarak Pearson korelasyon testinde 0.3 etki büyüklüğü, 0.90 güç ve 0.05 tip I hata payı alınmış ve ulaşılması gereken en az hemşire sayısı 92 olarak saptanmıştır. Çalışma 118 hemşire ile tamamlanmıştır ve daha sonra çalışmada kullanılan test tiplerinin gerçekleşen güç analizi sonuçları hesaplanmıştır (Tablo 1).

Tablo 1. Araştırmada Kullanılan Test Tiplerine Göre Gerçekleşen Güç Analizi Sonuçları

\begin{tabular}{|l|l|}
\hline Test Tipi & Gerçekleşen Güç Aralığı \\
\hline $\mathrm{t}$ testi & $0.80-1.00$ \\
\hline ANOVA & 1.00 \\
\hline
\end{tabular}

Veri Toplama Araçları

Kişisel Bilgi Formu

Form, katılımcıların sosyo-demografik özellikleri ve mesleki bilgilerini belirlemek amacıyla araştırmacı tarafından literatüre dayanarak hazırlanmış olup, toplam 14 sorudan oluşmuştur 3,7,12,13. Bunlar katılımcıların; yaş, cinsiyet, medeni durum, çocuk sayısı, eğitim durumu, mesleği isteyerek seçme durumu, çalışmakta olduğu birim, çalışma saatleri, pozisyon, çalışma yılı ve çalışılan önceki bölümler gibi tanıtıcı ve mesleki özelliklerini belirleyen sorulardır.

\section{Çalışanlar İçin Yaşam Kalitesi Ölçeği (ÇYKÖ)}

Çalışanların Yaşam Kalitesi Ölçeği, B. Hudnall Stamm tarafından mesleki tatmin, eşduyum yorgunluğu ve tükenmişlik belirtilerini saptamak amacıyla 2005 yılında geliştirilmiştir. 30 madde ve üç alt ölçekten oluşan bir öz bildirim değerlendirme aracıdır. Mesleki tatmin (compassion satisfaction), çalışanın kendi mesleği veya işiyle ilgili bir alanda yardıma ihtiyacı olan bir başka kişiye yardım etmesi sonucunda duyduğu tatmin ve memnuniyet duygusunu ifade eder. Bu alt ölçekten alınan yüksek puan yardım eden olarak memnuniyet veya tatmin duygusunun düzeyini gösterir. Ölçekteki 3, 6, 12, 16, 18, 20, 22, 24, 27, 30. maddeler mesleki tatmini ölçen maddelerdir. İkinci alt ölçek olan tükenmişlik (burnout) alt ölçeği, umutsuzluk, iş yaşamında oluşan sorunlarla başa çıkmada zorluk yaşanmasıyla ortaya çıkan tükenmişlik duygusunu ölçen bir testtir. Bu ölçekten alınan yüksek puan, tükenmişlik düzeyinin yüksek olduğunu gösterir. Ölçekteki 1, 4, 8, 10, 15, 17, 19, 21, 26, 29. maddeler tükenmişliği ölçen maddelerdir. Üçüncü ölçek olan eşduyum yorgunluğu (compassion fatigue) alt ölçeği, stres verici olayla karşılaşma sonucunda ortaya çıkan belirtileri ölçmek için oluşturulmuş bir testtir. Ölçekteki 2, 5, 7, 9, 11, 13, 14, 23, 25, 28. Maddeler bu durumu ölçmek için geliştirilmiş maddelerdir. Bu ölçekten alınan yüksek puan, eşduyum yorgunluğu düzeyinin yüksek 
olduğunu gösterir. Ölçekten elde edilen puanların değerlendirilmesi aşamasında 1, 4, 15, 17 ve 29. maddeler ters çevrilerek hesaplanması gereken maddelerdir. Ölçekteki maddelerin değerlendirilmesi "Hiçbir zaman" (0) ile "Çok sık" (5) arasında değişen altı basamaklı bir çizelge üzerinden yapılmıştır. Ölçeğin Cronbach Alpha güvenirlik değerleri mesleki tatmin boyutu için $\alpha=0.87$, tükenmişlik boyutu için $\alpha=0.72$, eşduyum yorgunluğu boyutu için $\alpha=0.80$ olarak bulunmuştur ${ }^{7}$. Bu çalışmadaki değerleri ise sırasıyla, $\alpha=0.90,0.76,0.82^{\prime}$ dir.

\section{Verilerin Toplama Araçlarının Uygulanması}

Veri toplama araçlarının uygulanmasında, araştırmacı Nisan-Mayıs 2017 tarihlerinde Akdeniz Üniversitesi Hastanesinde çalışmakta olan 670 hemşireye bireysel olarak ulaşmış ve araştırmaya katılmaya davet etmiştir. Kabul eden hemşirelere araştırmacı tarafından aydınlatılmış onam formu okutulup anlamaları sağlandıktan sonra imzalatılmıştır. Ardından Kişisel Bilgi Formu ve ÇYKÖ verilerek doldurmaları talep edilmiştir. Hemşirelerin formları doldurmaları yaklaşık 10 dakika sürmüştür. Araştırma 118 hemşire ile tamamlanmıştır.

\section{Verilerin Analizi}

Veriler, SPSS 20.0 (IBM SPSS Statistics 20) programında tek yönlü ANOVA ve $\mathrm{t}$ testi kullanılarak analiz edilmiştir. Normalliği değerlendirmek için Kolmogorow- Smirnov normallik testi, varyans homojenliğini değerlendirmek için de Levene testi kullanılmıştır. Değişkenler arasındaki ilişkiyi değerlendirmek amacıyla Pearson korelasyon analizi yapılmıştır.

\section{Araştırmanın Etik Boyutu}

Araştırmanın yapılabilmesi için etik onay Akdeniz Üniversitesi Tıp Fakültesi Klinik Araştırmalar Etik Kurulu'ndan (24.02.16, karar no:146), araştırma uygulama izni Akdeniz Üniversitesi Hastanesi Başhekimliği'nden alınmıştır. Araştırmada kullanılacak ölçek için kullanım izin yazısı ve araştırmaya katılmayı kabul eden bireylerden aydınlatılmış onam alınmıştır.

\section{Araştırmanın Sınırlılıkları}

$\mathrm{Bu}$ araştırmanın verileri yalnızca çalışmanın yapıldığ üniversite hastanesinde görevli hemşirelerin görüşleriyle sınırlı olduğundan, sonuçlar örneklem dışına genellenemez. Araştırma tasarımına bağlı olmaksızın, kurumdaki hemşirelerin tamamının araştırmaya katılmak istememesi de araştırmanın sınırlılığı olarak düşünülmüştür.

\section{BULGULAR}

Araştırmanın verilerini değerlendirirken öncelikle Kolmogorov simirnov normallik testi yapılmıştır ve buna göre araştırmanın değişkenleri normal dağılmaktadır. Ardından hemşirelerin tanıtıcı ve mesleki özellikleri incelenmiştir (Tablo 2).
Tablo 2. Hemşirelerin Tanıtıcı ve Mesleki Özellikleri ( $n=118$ )

\begin{tabular}{|c|c|c|c|c|c|}
\hline $\begin{array}{l}\text { Tanıtıcı } \\
\text { Özellikler }\end{array}$ & $\mathrm{n}$ & $\%$ & $\begin{array}{l}\text { Mesleki } \\
\text { Özellikler }\end{array}$ & $\mathbf{n}$ & $\%$ \\
\hline Cinsiyet & & & \multicolumn{3}{|c|}{ Mesleği kendi isteğiyle seçme } \\
\hline Kadın & 113 & 95.8 & Evet & 64 & 54.2 \\
\hline Erkek & 5 & 4.2 & Hayır & 54 & 45.8 \\
\hline Yaş & \multicolumn{2}{|c|}{$\overline{\mathrm{X}} \pm \mathrm{SS} 31.52 \pm 6.52$} & \multicolumn{3}{|c|}{ Mevcut bölümde çalışma süresi } \\
\hline $19-30$ & 61 & 51.7 & 5 yıldan az & 81 & 68.6 \\
\hline $\begin{array}{l}31 \text { ve } \\
\text { üzeri }\end{array}$ & 57 & 48.3 & 5 yıl ve üzeri & 37 & 31.4 \\
\hline \multicolumn{3}{|c|}{ Medeni Durum } & \multicolumn{3}{|c|}{ Hemşirelikte çalışma süresi } \\
\hline Bekar & 74 & 62.7 & 5 yıldan az & 30 & 25.4 \\
\hline Evli & 44 & 37.3 & $5-10 \mathrm{yll}$ & 44 & 37.3 \\
\hline \multicolumn{3}{|c|}{ Çoçuk sayısı } & 10 yıldan fazla & 44 & 37.3 \\
\hline Yok & 63 & 53.4 & \multicolumn{3}{|l|}{ Çalışma saatleri } \\
\hline 1 çocuk & 29 & 24.5 & Gündüz & 34 & 28.8 \\
\hline 2 çocuk & 26 & 22.1 & Vardiyalı & 84 & 71.2 \\
\hline \multicolumn{3}{|c|}{ Eğitim durumu } & \multicolumn{3}{|l|}{ Pozisyon } \\
\hline $\begin{array}{l}\text { Lise ve } \\
\text { önlisans }\end{array}$ & 11 & 9.3 & $\begin{array}{l}\text { Sorumlu } \\
\text { hemşire }\end{array}$ & 16 & 13.5 \\
\hline Lisans & 88 & 74.6 & $\begin{array}{l}\text { Klinik } \\
\text { hemşiresi }\end{array}$ & 89 & 75.4 \\
\hline Lisansüstü & 19 & 16.1 & $\begin{array}{l}\text { Diğer (Plk., } \\
\text { eğitim vb.) }\end{array}$ & 13 & 11.0 \\
\hline & & & \multicolumn{3}{|c|}{ Şu an çalışılan birimler } \\
\hline & & & Dahili & 47 & 39.8 \\
\hline & & & Cerrahi & 36 & 30.5 \\
\hline & & & Yoğun bakım & 18 & 15.3 \\
\hline & & & Ameliyathane & 5 & 4.2 \\
\hline & & & Acil & 12 & 10.2 \\
\hline Toplam & 118 & 100.0 & Toplam & 118 & 100.0 \\
\hline
\end{tabular}

$\overline{\mathrm{X}} \pm \mathrm{SS}$ : Ortalama, standart sapma

Hemşirelere ait tanıtıcı özellikler incelendiğinde, büyük çoğunluğun (\%95.8) kadın olduğu saptanmıştır. Hemşirelerin \%62.7'si bekar olup, \%53.4'ü çocuk sahibi değildir. Hemşirelerin eğitim düzeyi incelendiğinde \%74.6'sının lisans mezunu olduğu görülmektedir. Araştırmaya katılan hemşirelerin yaş aralığı 19-30 (\%51.7) ve 31 ve üzeri (\%48.3) olarak gruplandırılmış olup bu gruplarda bulunan hemşire sayısı birbirine yakın düzeydedir. Hemşirelerin mesleki özellikleri incelendiğinde ise, çalışmaya katılan hemşirelerin \%54.2'si mesleğini isteyerek seçmiştir. Şu an bulunduğu bölümde beş yıldan fazla çalışan hemşire sayısı oranı \% 31.4'dür. Katılımcıların hemşirelikte çalışma süresine bakıldığında \%25.4'ünün beş yıldan az çalışma süresine sahip olduğu görülmektedir. Hemşirelerin \%71.2'si vardiyalı çalışmaktadır. Sadece gündüz çalışan hemşire oranı \%28.8'dir. Araştırmaya katılan hemşirelerin \%75.4 kliniklerde görev almaktadır. Hemşirelerin görev yaptığı birimler incelendiğinde en az katılımın (\%4.2) ameliyathane alanından olduğu görülmektedir (Tablo 2). 
Tablo 3. Hemşirelerin Yaş Grubu, Çocuk Sayısı, Mesleği Seçme ve Çalışma Saatlerine Göre Ortalama ÇYKÖ Puanları Dağııımı ( $n=118)$

\begin{tabular}{|c|c|c|c|}
\hline & \multicolumn{3}{|c|}{ ÇYKÖ Alt Ölçekleri } \\
\hline & $\begin{array}{l}\text { Mesleki } \\
\text { tatmin } \\
\bar{X} \pm S S\end{array}$ & $\begin{array}{l}\text { Tükenmişlik } \\
\bar{X} \pm S S\end{array}$ & $\begin{array}{l}\text { Eşduyum } \\
\text { yorgunluğu } \\
\overline{\mathrm{X}} \pm \mathrm{SS}\end{array}$ \\
\hline \multicolumn{4}{|l|}{ Yaş grupları } \\
\hline $19-30$ & $32.63 \pm 7.83$ & $19.91 \pm 6.61$ & $18.23 \pm 8.49$ \\
\hline 31 ve üzeri & $34.49 \pm 9.82$ & $16.98 \pm 6.20$ & $15.05 \pm 7.77$ \\
\hline $\mathrm{p}$ & 0.262 & 0.014 & 0.037 \\
\hline \multicolumn{4}{|l|}{ Çocuk sayısı } \\
\hline Yok & $32.33 \pm 8.73$ & $19.50 \pm 7.02$ & $18.39 \pm 8.74$ \\
\hline 1 çocuk & $34.10 \pm 8.23$ & $17.27 \pm 5.78$ & $13.79 \pm 6.54$ \\
\hline 2 çocuk & $35.80 \pm 9.63$ & $17.42 \pm 5.98$ & $15.80 \pm 8.05$ \\
\hline $\mathrm{F}$ & 1.508 & 1.616 & 3.399 \\
\hline $\mathrm{p}$ & 0.226 & 0.203 & $0.037 *$ \\
\hline \multicolumn{4}{|c|}{ Mesleği isteyerek seçme durumu } \\
\hline Evet & $35.85 \pm 7.70$ & $17.70 \pm 6.33$ & $17.07 \pm 8.87$ \\
\hline Hayır & $30.77 \pm 9.40$ & $19.44 \pm 6.74$ & $16.24 \pm 7.55$ \\
\hline $\mathrm{p}$ & 0.002 & 0.152 & 0.586 \\
\hline \multicolumn{4}{|c|}{ Çalışma saatleri } \\
\hline Gündüz & $35.00 \pm 8,65$ & $16.58 \pm 5.68$ & $16.11 \pm 7.01$ \\
\hline Vardiyalı & $32.94 \pm 8,92$ & $19.27 \pm 6.75$ & $16.92 \pm 8.76$ \\
\hline $\mathrm{p}$ & 0.254 & 0.043 & 0.632 \\
\hline
\end{tabular}

Tablo 3 incelendiğinde; $19-30$ ve 31 yaş ve üzeri yaş grubundaki hemşireler arasında tükenmişlik puanı bakımından anlamlı farklılık vardır $(p<0.05)$. Hemşirelerin çocuk sahibi olma durumu veya çocuk sayısı incelendiğinde, mesleki tatmin ve tükenmişlik puanları bakımından farklılık bulunmamakla birlikte, eşduyum yorgunluğu puanlarında bir farklılık olduğu görülmüştür $(F=3.399, p=0.037)$. Bu farklıı̆̆ın kaynaklandığı grubu belirlemek amacıyla Post-Hoc testi yapılmıştır. Yapılan Levene testinde üç grubun varyansı birbirine eşit çıktığı için (eşduyum yorgunluğu levene istatistiği $=1.364, p=0.260$ ) post-hoc testlerden hassaslığı en fazla olan Scheffe testi yapılmıştır. Bunun sonucunda; çocuğu olmayanlar ile bir çocuğu olanlar arasında eşduyum yorgunluğu açısından bir farklılık olduğu görülmüştür. Çocuğu olmayanların eşduyum yorgunluğu puanları daha yüksek bulunmuştur ( $p=0.037)$. Mesleğini isteyerek seçen hemşirelerin mesleki tatmin puanları yüksek, vardiyalı çalışan hemşirelerin ise tükenmişlik puanları gündüz çalışan hemşirelere göre daha yüksek bulunmuştur.

Tablo 4. Hemşirelerin ÇYKÖ alt boyutlarına ait puan ortalamaları $(n=118)$

\begin{tabular}{|l|l|}
\hline ÇYKÖ Alt Ölçek Boyutları & $\begin{array}{l}\text { Ortalama Puanlar } \\
\mathbf{X} \pm \text { SS }\end{array}$ \\
\hline Mesleki Tatmin & $33.53 \pm 8.85$ \\
\hline Tükenmişlik & $18.50 \pm 6.55$ \\
\hline Eşduyum Yorgunluğu & $16.69 \pm 8.27$ \\
\hline
\end{tabular}

$\overline{\mathrm{X}} \pm$ SS: Ortalama, standart sapma

Tablo 4'de araştırmaya katılan 118 hemşirenin ÇYKÖ alt boyutlarından aldıkları puan ortalamaları verilmiştir. Hemşirelerin ölçeğin alt boyutları olan mesleki tatmin puan ortalaması $33.53 \pm 8.85$, tükenmişlik puan ortalaması $18.50 \pm 6.55$ ve eşduyum yorgunluğu puan ortalaması ise $16.69 \pm 8.27$ 'dir.

Tablo 5. Hemşirelerin Mesleki Tatmin, Tükenmişlik ve Eşduyum Yorgunluğu Düzeyleri Arasındaki ilişsi ( $n=118)$

\begin{tabular}{|l|l|l|}
\hline Değişken & Tükenmişlik & Eşduyum yorgunluğu \\
\hline Mesleki tatmin & -0.618 & -0.139 \\
\hline Tükenmişlik & - & 0.580 \\
\hline
\end{tabular}

$\mathrm{Bu}$ araştırmada yaşam kalitesi ölçeği alt boyutları olan mesleki tatmin, tükenmişlik ve eşduyum yorgunluğu puanları arasındaki ilişki de incelenmiştir (Tablo 5). Buna göre mesleki tatmin ile tükenmişlik arasında ters yönlü ve orta düzey bir ilişki bulunmaktadır ( $r=-0.618 ; p<0.001)$. Mesleki tatmin ve eşduyum yorgunluğu puanları arasında istatiksel olarak anlamlı bir ilişki bulunmamıştır ( $r=-0.139$; $p=0.134)$. Hemşirelerin tükenmişlik ve eşduyum yorgunluğu puanları arasında ise pozitif ve anlamlı bir ilişki olduğu saptanmıştır $(r=0.580 ; p<0.001)$.

\section{TARTIŞMA}

Çalışanların yaşam kalitesinin pozitif göstergesi mesleki tatmin iken, negatif göstergeleri tükenmişlik ve eşduyum yorgunluğudur ${ }^{14}$. Bu araştırmada da hemşirelerin mesleki tatmin, tükenmişlik ve eşduyum yorgunluğu düzeyleri ve ilişkili faktörler açısından önemli bulgulara ulaşımıştır. Buna göre hemşirelerin bazı tanıtıcı ve mesleki özellikleriyle ÇYKÖ alt boyutları arasında istatistiksel olarak anlamlı sonuçlara ulaşılmıştır.

Çalışmada 19-30 yaş grubunda olan hemşirelerin tükenmişlik ve eşduyum yorgunluğu düzeyinin, 31 ve üzeri yaş grubuna göre yüksek olduğu saptanmıştır. Benzer şekilde Kaya ve arkadaşlarının (2010) bir devlet hastanesinde çalışan hemşirelerin tükenmişlik düzeyi üzerine yaptıkları çalışmada genç yaşta ve mesleğe yeni başlamış hemşirelerin tükenmişlik düzeylerinin yüksek olduğu saptanmıştır ${ }^{15}$. Ancak konuyla ilgili literatürde karşıt sonuçlar bulunmaktadır. Günüşen ve Üstün (2008) bir üniversite hastanesinde çalışan hemşireler ile Metin ve Özer (2007) ise sağlık profesyonelleriyle yaptığı çalışmada hemşirelerin tükenmişlik düzeyi ile yaş grupları arasında ilişki saptamamıştır ${ }^{13,16}$. Literatürde farklı sonuçlar olmasına rağmen pek çok çalışmada yaş ve tükenmişliğin ilişkili olduğu anlaşılmıştır ${ }^{12,15,17-20}$. Bunun nedeni olarak hemşirelerin deneyimsiz ve genç olması sebebiyle baş etme becerilerini etkin kullanamaması düşünülmüştür. Nitekim Taycan ve arkadaşları (2006) hemşirelerde depresyon ve tükenmişlik düzeyinin sosyo-demografik özelliklerle ilişkisini incelemiş oldukları çalışmada yaştaki artışa bağıı olarak hemşirelerin kendilerini mesleklerinde daha yeterli ve başarılı hissettikleri sonucuna ulaşmıştır ${ }^{20}$. Bu görüşü Brewer ve Shapard (2004) meta-analiz çalışmasında, genç yaşta olan ve mesleki olarak tecrübesiz bireylerde tükenmişliğin daha sık ve ağır seyrettiğini saptayarak desteklemiştir ${ }^{21}$. Kılıç (2018) hemşirelerde travmatik stres belirtileri, mesleki tatmin tükenmişlik ve eşduyum yorgunluğunu incelediği çalışmasında, genç hemşirelerde eşduyum yorgunluğu 
puanlarını daha yüksek saptamıştır ${ }^{22}$. Ayrıca eşduyum yorgunluğu ile birlikte anılan dolaylı travma, ikincil travma sonrası stres bozukluğu kavramına ilişkin risk faktörleri incelendiğinde, genç ve deneyimsiz hemşirelerin daha hassas olduğu savunulmaktadır ve bu nedenle genç hemşirelerin eşduyum yorgunluğu bakımından riskli olduğu düşünülmektedir ${ }^{23}$. Bu durum deneyimli çalışanların etkili bir şekilde bilişsel ve davranışsal baş etme becerilerini kullanabilmeleriyle açıklanabilir.

Hemşirelerin yaşam kalitelerini etkileyen diğer bir özellik ise çocuk sahibi olma durumudur. Bu çalışmada çocuk sahibi olmayan hemşirelerin, eşduyum yorgunluğu düzeyi yüksek bulunmuştur. Bununla birlikte literatürde bu bulguyu desteklemeyen sonuçlar bulunmaktadır ${ }^{22}$. Ayrıca literatürde çocuk sahibi olmanın tükenmişlikle ilişkisine değinen çalışmalar da yer almaktadır. Kavlu ve Pınar'ın (2009), acil servislerde çalışan hemşirelerin tükenmişlik ve iş doyumlarının yaşam kalitesine etkisini inceledikleri çalışmada çocuk sahibi olmayan hemşirelerin duygusal tükenmişlik puanlarının daha yüksek olduğu belirtilmiştir ${ }^{12}$. Bu durumun, çocuk sahibi olmanın sosyal destek sağlaması ve çocuk yetiştirmenin pozitif ve umut verici duygu oluşturmasıyla ilişkili olduğu düşünülebilir.

Bu çalışmada önemli bir diğer bulgu mesleğini isteyerek seçmiş olan hemşirelerin mesleki tatmin düzeyinin, mesleğini istemeyerek seçen hemşirelere göre daha yüksek olmasıdır. Kundak ve arkadaşları (2015) hemşirelik mesleğinde iş tatmini ve motivasyonla ilgili çalışmalarında, mesleğini kendi isteğiyle seçen hemşirelerde iş tatmini düzeyinin daha yüksek olduğunu saptamıştır ${ }^{24}$. Buna göre mesleğini isteyerek seçme durumunun hemşirelerin motivasyonunu etkileyerek, mesleki tatmin düzeyini arttırdığı düşünülebilir. Bireylerin mesleğini isteyerek seçmemesi ve bunun sonucunda işini severek yapmaması, bireylerdeki anksiyete düzeyini artırır ${ }^{25}$. Bu durumun tükenmişlik ve eşduyum yorgunluğuna yol açabileceği düşünülmektedir.

Bir diğer önemli bulgu ise vardiyalı çalışan hemşirelerin tükenmişlik düzeyinin gündüz çalışanlara göre daha yüksek olduğunun saptanmış olmasıdır. Çalışmadaki bu bulgular literatür bilgileri ile benzerlik göstermektedir. Kavlu ve Pınar (2009) acil servislerde çalışan hemşirelerin tükenmişlik ve iş doyumlarının yaşam kalitesine etkisini inceledikleri çalışmada, vardiya usulü çalışan hemşirelerde tükenmişlik alt boyutu olan kişisel başarısızlık puanlarını daha yüksek bulmuştur ${ }^{12}$. Tekir ve arkadaşları (2016) sağlık çalışanları üzerinde yaptıkları çalışmada, nöbet tutarak çalışanların, gündüz çalışanlara göre tükenmişlik düzeyinin yüksek olduğunu bulmuştur ${ }^{26}$. Kılıç (2018) ise, hemşirelerin, çalışma biçimi ile mesleki tatmin, tükenmişlik ve eşduyum yorgunluğu arasında ilişki saptamamıştır ${ }^{22}$. Hemşirelerde vardiyalı çalışmanın bazı olumsuz sonuçları oluşmaktadır. Çalık ve arkadaşları (2015) vardiyalı çalışmanın, hemşireler üzerinde fizyolojik, psikolojik sağlıkları, sosyal yaşamları ve kendi güvenlikleri üzerinde olumsuz etkileri olduğunu saptamıştır ${ }^{27}$. Buna göre vardiyalı çalışmanın hemşirelerin tükenmişlik oranını yükselttiği ve yaşam kalitesini olumsuz etkileyerek çeşitli sorunlara yol açtığı düşünülebilir.
Bu bulgulara dayanarak hemşirelerin yaşam kalitesinin, yaş, çocuk sahibi olma durumları, mesleğini isteyerek seçme ve vardiyalı çalışma düzeniyle ilişkili olduğu söylenebilir. Ayrıca bu çalışmada, cinsiyet, eğitim durumu, medeni durum, çalışılan bölüm ve pozisyon, çalışmakta olunan bölümdeki çalışma süresi ve toplam çalışma yılının hemşirelerin yaşam kalitesi üzerinde etkili olmadığı saptanmıştır.

$\mathrm{Bu}$ çalışmaya katılan hemşirelerin mesleki tatmin, tükenmişlik ve eşduyum yorgunluğu alt boyutlarından aldıkları puan ortalamaları, aynı ölçeği kullanan ve katılımcıları hemşire olan Kılıç'ın (2018) çalışması ile benzerlik göstermektedir22. Araştırmaya katılan hemşirelerin, mesleki tatmin ve tükenmişlik düzeyleri arasında negatif yönlü ve orta düzey bir ilişki olduğu bulunmuş olup ( $r=-0.618 ; p<0.001$ ), literatürde bu bulguyu destekleyen çalışmalar bulunmaktadır22,28. Bu durumda tükenmişlik düzeyini azaltmada, mesleki tatmin düzeyini artırmak da bir yöntem olabilmektedir. Hinderer ve arkadaşları (2014) hemşirelerde mesleki tatmini arttıran stratejileri inceleyerek, tükenmişlik ve eşduyum yorgunluğunun azaltılabileceğini belirtmiştir ${ }^{29}$. Hemşirelerin tükenmişlik ve eşduyum yorgunluğu arasında pozitif yönde ve anlamlı bir ilişki bulunmaktadır $(r=0.580 ; p<0.001)$. Bu sonuç, literatür bulgularıyla benzerlik göstermektedir ${ }^{22,28}$. Hemşirelerin mesleki tatmin ve eşduyum yorgunluğu arasında anlamlı bir ilişki bulunmamıştır $(r=-0.139 ; p=0.134)$. Bu bulguya ilişkin literatürde farklı sonuçlar bulunmaktadır. Kılıç'ın (2018) çalışması bu sonucu desteklerken ${ }^{22}$, Polat ve Erdem'in (2017) çalışmasında mesleki tatmin oranı arttıkça, eşduyum yorgunluğunun azaldığını saptamıştır ${ }^{28}$. Smart ve arkadaşları da (2014) sağlık çalışanları ile yaptıkları araştırmada mesleki tatmin ve eşduyum yorgunluğu arasında negatif yönlü ilişki saptamıştır ${ }^{30}$.

Sonuç olarak yaşam kalitesinin temel parametreleri olan mesleki tatmin, tükenmişlik ve eşduyum yorgunluğunun kişisel ve mesleki özellikler ile ilişkili olduğu saptanmıştır. Buna karşın hemşirelerin kurumdan ayrılmak, hemşireliği bırakmak, bölüm değişikliği, tam-zamanlıdan yarı-zamanlı çalışma saatlerine geçmek, vardiyaları değiştirmek ve çalışılan gün sayısını sınırlamak gibi etkisiz baş etme stratejileri geliştirdiği belirtilmektedir ${ }^{31}$. Bu nedenle hemşirelerin beden ve ruh sağlığının korunması, çalışma yaşamının ve işyerinin zorlu koşullarından, toplumsal kaynaklı zararlı etkenlerden en az düzeyde etkilenmesinin sağlanması son derece önemlidir. Mesleki tatminsizlik, tükenmişlik ve eşduyum yorgunluğunun risk faktörlerini ve belirtilerini tanımanın ilk adım, önleme ve iyileştirme çalışmalarının bir sonraki adım olacağı öngörüsü 6 dikkate alındığında çalışma sonuçlarının bu bağlamda veri kaynağı olacağı düşünülmektedir.

\section{SONUÇ ve ÖNERILER}

\section{Bu araştırmanın bulgularına göre;}

- 31 ve üzeri yaş aralığındaki hemşirelerin, 19-30 yaş aralığındaki hemşirelerden daha az tükenmişlik ve eşduyum yorgunluğu yaşadığı saptandığından genç hemşirelerde tükenmişlik ve eşduyum yorgunluğu ile baş etme becerilerini geliştiren eğitim planlamalarının yapılması, 
- Mesleğini isteyerek seçen hemşirelerin mesleki tatmin oranı yüksek bulunduğundan, mesleğe yeni başlayan ve özellikle mesleğe istemeyerek başlayan hemşirelere etkin uyum programları düzenlenmesi,

- Vardiyalı çalışan hemşirelerin tükenmişlik oranı gündüz mesaisinde çalışan hemşirelere göre yüksek bulunduğundan, vardiyalı çalışan hemşirelerin mola ve izin kullanımına özen gösterilmesi ve vardiyalı çalışma koşullarının olumsuz yönlerini ortaya çıkaran araştırmaların planlanması,

- Hemşirelerin mesleki tatmin, tükenmişlik ve eşduyum yorgunluğunu etkileyen faktörleri tanımlayan nitel araştırma çalışmalarının planlanması önerilmektedir.

Ayrıca çocuk sahibi olmayan hemşirelerin eşduyum yorgunluğu düzeyinin yüksek olduğu ve hemşirelerin mesleki tatmin ile tükenmişlik düzeyi arasında negatif yönlü ve orta düzey bir ilişki olduğu, tükenmişlik düzeyi ve eşduyum yorgunluğu düzeyi arasında ise pozitif ve anlamlı bir ilişki olduğu saptanmıştır. Bu bağlamda çalışmanın $1 . H_{1}$ ve $2 . \mathrm{H}_{1}$ hipotezleri doğrulanmıştır.

Etik Kurul Onayı: Akdeniz Üniversitesi Klinik Araştırmalar Etik Kurulu'ndan onay alınmıştır (24.02.16, Karar Numarası: 146).

Çıkar Çatışması: Yoktur.

Finansal Destek: Bildirilmemiştir.

Katılımcı Onamı: Katılımcılardan bilgilendirilmiş onam

alınmıştır.

Yazar katkıları:

Araştırma dizaynı: YÇY, KB

Veri toplama: YÇY

Literatür araştırması: YÇY, KB

Veri Analizi: YÇY, KB

Makale yazımı: YÇY, KB

Teşekkür: Bu araştırmaya istatistik desteği sağlayan Prof. Dr. Ayşe Kuruüzüm'e ve çalışmaya katılmayı kabul ederek değerli vakitlerini ayıran tüm meslektaşlarımıza teşekkür ederiz.

Ethics Committee Approval: Approval was obtained from Clinical Research Ethics Committee of Akdeniz University (24.02.16, Decision Number:146).

Confict of Interest: Not reported.

Funding: None.

Exhibitor Consent: Informed consent was obtained from the participants.

Author contributions:

Study design: YCY, KB

Data collection: $Y C Y$

Literature search: YCY, KB

Data analysis: YCY, KB

Drafting manuscript: $Y C Y, K B$

Acknowledgement: We would like thank to Prof. Dr. Ayşe Kuruüzüm, who provided statistical support for this study, and all our colleagues who agreed to participate in the study and spend their valuable time.

\section{KAYNAKLAR}

1. Pektekin Ç. Hemşirelik felsefesi, kuramlar-bakım modelleri ve politik yaklaşımlar. İstanbul: İstanbul Tıp Kitabevi; 2013.

2. Figley CR. Compassion fatigue: Psychotherapists' chronic lack of self care. J Clin Psychol. 2002;58(11):1433-1441.

3. Hiçdurmaz D, İnci FA. Eşduyum yorgunluğu: Tanımı, nedenleri ve önlenmesi. Psikiyatride Güncel Yaklaşımlar-Current Approaches in Psychiatry. 2015;7(3):295-303.

4. Rego A, Godinho L, McQueen A, Cunha MP. Emotional intelligence and caring behaviour in nursing. The Service Industries Journal. 2010;30(9):1419-1437.

5. Gök GA. Merhamet etmenin dayanılmaz ağırlığı: Hemşirelerde merhamet yorgunluğu. Süleyman Demirel Üniversitesi İktisadi ve İdari Bilimler Fakültesi Dergisi. 2015;20(2):299-313.

6. Figley CR. Treating compassion fatigue: Routledge; 2002.

7. Yesil A, Ergün Ü, Amasyali C, Er F, Olgun NN, Aker AT. Çalışanlar için yaşam kalitesi ölçeği Türkçe uyarlaması geçerlik ve güvenirlik çalışması. Noro Psikiyatr Ars. 2010;47(2):111-117.

8. Lombardo B, Eyre C. Compassion fatigue: A nurse's primer. Online J Issues Nurs. 2011;16(1):3.

9. Batıgün $A D$, Şahin $\mathrm{NH}$. İş stresi ve sağlık psikolojisi araştırmaları için iki ölçek: A-tipi kişilik ve iş doyumu. Türk Psikiyatri Derg. 2006;17(1):25-32.

10. Yıldııım MH, İçerli L. Tükenmişlik Sendromu: Maslach ve Kopenhag Tükenmişlik Ölçeklerinin Karşılaştırmalı Analizi. Organizasyon ve Yönetim Bilimleri Dergisi. 2010;2(1):123-131.

11. Tilev S, Beydağ KD. Hemşirelerin iş doyum düzeyi. Sağlık ve Hemşirelik Yönetimi Dergisi. 2014;3(1):140147.

12. Kavlu I, Pınar R. Acil servislerde çalışan hemşirelerin tükenmişlik ve iş doyumlarının yaşam kalitesine etkisi. Turkiye Klinikleri J Med Sci. 2009;29(6):1543-5.

13. Günüşen N, Üstün B. Bir üniversite hastanesinde çalişan hemşirelerin tükenmişlik düzeyi ve etkileyen faktörlerin incelenmesi. Atatürk Üniversitesi Hemşirelik Yüksekokulu Dergisi. 2008;11(4):48-58.

14. McHugh MD, Kutney-Lee A, Cimiotti JP, Sloane DM, Aiken LH. Nurses' widespread job dissatisfaction, burnout, and frustration with health benefits signal problems for patient care. Health Affairs. 2011;30(2):202-210.

15. Kaya N, Kaya H, Ayık SE, Uygur E. Burnout of nurses who work in a government hospital. Journal of Human Sciences. 2010;7(1):401-419.

16. Metin Ö, Özer FG. Hemşirelerin tükenmişlik düzeyinin belirlenmesi. Atatürk Üniversitesi Hemşirelik Yüksekokulu Dergisi. 2007;10(1):58-66.

17. Ergin C. Akademisyenlerde tükenmişlik ve çeşitli stres kaynaklarının incelenmesi. Hacettepe Üniversitesi Edebiyat Fakültesi Dergisi. 1995;12(1-2):37-50.

18. Maslach C, Schaufeli WB, Leiter MP. Job burnout. Annu Rev Psychol 2001;52(1):397-422. 
19. Çimen M, Ergin C. Türk Silahlı Kuvvetleri sağlık personelinin tükenmişlik düzeylerinin incelenmesi. Gülhane Tıp Dergisi. 2001;43(2):169-176.

20. Taycan O, Kutlu L, Çimen S, Aydın N. Bir üniversite hastanesinde çalışan hemşirelerde depresyon ve tükenmişlik düzeyinin sosyodemografik özelliklerle ilişkisi. Anadolu Psikiyatri Derg. 2006;7(2):100-108.

21. Brewer EW, Shapard L. Employee burnout: A metaanalysis of the relationship between age or years of experience. Human Resource Development Review. 2004;3(2):102-123.

22. Kılıç S. Devlet Hastanesinde Çalışan Hemşirelerde Travmatik Stres Belirtileri, Mesleki Tatmin Tükenmişlik Ve Eşduyum Yorgunluğunun İncelenmesi [Yüksek lisans tezi]. Nevşehir: Nevşehir Hacı Bektaş Veli Üniversitesi; 2018.

23. Çolak B, Şişmanlar ŞG, Karakaya I, Etiler N, Biçer Ü. Çocuk cinsel istismarı olgularını değerlendiren meslek gruplarında dolaylı travmatizasyon. Anadolu Psikiyatri Derg. 2012;13(1):51-58.

24. Kundak Z, Taş HÜ, Keleş A, Eğicioğlu H. Bir üniversite hastanesinde hemşirelik mesleğinde iş tatmini ve motivasyon. Kocatepe Tıp Dergisi. 2015;16(1):1-10.

25. Durmuş $S$, Günay $\mathrm{O}$. Hemşirelerde iş doyumu ve anksiyete düzeyini etkileyen faktörler. Erciyes Tıp Dergisi. 2007;29(2):139-146.

26. Tekir Ö, Çevik C, Arık S, Çetin G. Sağlık çalışanlarının tükenmişlik, iş doyumu düzeyleri ve yaşam doyumunun incelenmesi. Kırıkkale Üniversitesi Tıp Fakültesi Dergisi. 2016;18(2):51-63.

27. Çalık KY, Aktaş S, Bulut HK, Anahar EÖ. Vardiyalı ve nöbet sistemi şeklindeki çalışma düzeninin hemşireler üzerine etkisi. Sağlık Bilimleri ve Meslekleri Dergisi. 2015;2(1):33-45.

28. Polat FN, Erdem R. Merhamet yorgunluğu düzeyinin çalışma yaşam kalitesi ile ilişkisi: Sağlık profesyonelleri örneği. Süleyman Demirel Üniversitesi Sosyal Bilimler Enstitüsü Dergisi. 2017;1(26):291-312.

29. Hinderer KA, VonRueden KT, Friedmann E, McQuillan KA, Gilmore R, Kramer B, et al. Burnout, compassion fatigue, compassion satisfaction, and secondary traumatic stress in trauma nurses. J Trauma Nurs. 2014;21(4):160-169.

30. Smart D, English A, James J, Wilson M, Daratha KB, Childers $\mathrm{B}$, et al. Compassion fatigue and satisfaction: A cross-sectional survey among US healthcare workers. Nursing\&Health Sciences. 2014;16(1):3-10.

31. Yoder EA. Compassion fatigue in nurses. Appl Nurs Res. 2010;23(4):191-197. 